\title{
Penerapan Pendekatan Contextual Teaching and Learning (CTL) untuk Meningkatkan Hasil Belajar Siswa SMPN 18 Sigi pada Materi Sistem Persamaan Linear Dua Variabel (SPLDV)
}

\author{
Hajerina \\ Program Studi Pendidikan Matematika, FKIP, Universitas Alkhairaat Pali \\ E-mail:hajrinahamid@gmail.com
}

\begin{abstract}
This research is a classroom action research with the aim to improve student learning result of SMPN 18 Sigi toward SPLDV. An alternative action used to achieve that goal by applying Contextual Teaching and Learning (CTL) approach which is a learning that relate material to real life situation both in groups and individuals which concists of 7 components, namely: (1) Contructivisme, (2) Quistioning, (3) Inquiry, (4) learning community, (5) modelling, (6) reflection, (7) authentic assessment. The subjects of this study were students of class VIII E SMPN 18 Sigi. The design of this study using the model Kemis and Mc Taggart consisting of the planning, action, observasion, and reflection. Based on the results of research shows that the learning activities have been running well and have increased in every cycle. This can be seen from the percentage of classical learning mastery. In the final test of cycle I reached the average student scoe of $72.22 \%$ and in the final test of cycle II increased to $83.33 \%$ in good qualification.
\end{abstract}

Keywords: Contextual Teaching and Learning (CTL) approach, Learning Outcomes, System of Linear Equations of Two Variables

\section{Abstrak}

Penelitian ini merupakan Penelitian Tindakan Kelas dengan tujuan untuk meningkatkan hasil belajar siswa SMPN 18 Sigi terhadap materi SPLDV. Alternatif tindakan yang digunakan untuk mencapai tujuan tersebut dengan menerapkan pendekaatan Contextual Teaching and Learning (CTL) yang merupakan suatu pembelajaran yang menghubungkan materi dengan situasi kehidupan nyata siswa baik secara kelompok maupun individu yang terdiri dari 7 komponen pembelajaran yaitu : (1) Kontruktivisme, (2) Bertanya, (3) Menemukan, (4) Masyarakat Belajar, (5) Pemodelan, (6) Refleksi, (7) Penilaian sebenarnya. Subyek penelitian ini adalah siswa kelas VIII E SMPN 18 Sigi. Rancangan penelitian ini menggunakan model Kemmis dan Mc Taggart yang terdiri dari tahap perencanaan, tahap tindakan, tahap observasi/ evaluasi dan tahap refleksi. Berdasarkan hasil penelitian menunjukkan bahwa aktivitas pembelajaran telah berjalan dengan baik dan mengalami peningkatan disetiap siklusnya. Hal tersebut dapat dilihat dari persentase ketuntasan belajar klasikalnya. Pada tes akhir siklus 1 mencapai rata-rata skor siswa yaitu 72,22 \% dan pada tes akhir siklus II meningkat menjadi 83,33 \% pada kualifikasi baik.

Kata Kunci: Pendekatan Contextual teaching and Learning (CTL), Hasil Belajar, Sistem Persamaan Linear Dua Variabel 


\section{Pendahuluan}

Matematika dapat membentuk seseorang mempunyai daya nalar yang tinggi dalam pemecahan masalah. Menyadari akan pentingnya matematika, pemerintah telah mewajibkan matematika untuk dipelajari sejak dibangku sekolah dasar (SD) hingga sekolah menengah atas (SMA). Hal ini tidak lain bertujuan untuk membekali siswa dengan kemampuan berpikir kritis, logis, sistematis, kreatif, efektif jujur dan disiplin dalam memecahkan masalah.

Berdasarkan pengamatan di kelas VIII E SMPN 18 Sigi, diperoleh informasi bahwa matematika merupakan salah satu mata pelajaran yang dianggap sulit oleh siswa. Hal ini terlihat dari hasil ujian tengah semester (UTS) siswa, yang memenuhi kriteria Ketuntasan Minimal (KKM) hanya 25\% hal ini disebabkan karena siswa kurang antusias mengikuti pelajaran. Siswa tidak aktif, enggan, takut dan malu untuk bertanya. Siswa hanya mendengarkan semua hal yang dijelaskan oleh guru selama proses kegiatan pembelajaran. Sehingga selama pembelajaran siswa menerima materi yang sudah jadi, siswa tidak ikut berfikir dan menggunakan pengalaman belajarnya. Keadaan tersebut, apabila didiamkan akan menyebabkan siswa semakin mengalami kesulitan dalam belajar.

Masalah yang terjadi pada pelaksanaan pembelajaran matematika tersebut, merupakan gambaran yang terjadi di SMPN 18 Sigi. Berdasarkan observasi antara guru dengan murid yang dilakukan saat tatap muka minggu terakhir bulan September diperoleh informasi bahwa rata-rata hasil belajar dalam pembelajaran matematika masih rendah dan belum optimal, khususnya pada materi Sistem Persamaan Linear Dua Variabel. Salah satu penyebabnya yaitu guru merupakan pusat belajar sedangkan siswa cenderung pasif dalam pembelajaran, sehingga kemampuan siswa dalam menyelesaiakan soal matematika masih kurang. Ini membuat siswa menjadi malas belajar dan cepat merasa bosan.

Dalam upaya mengatasi permasalahan tersebut, salah satu langkah penting yang harus dilakukan agar siswa lebih mudah memahami materi pembelajaran yaitu dengan menerapkan pendekatan CTL yang merupakan 
suatu konsepsi yang membantu guru mengaitkan isi materi pelajaran dengan keadaan dunia nyata.

Sehingga berdasarkan masalah tersebut, maka peneliti terdorong untuk melakukan penelitian yang menerapkan pendekatan CTL pada materi sistem persamaan linear dua variabel, melalui penelitian tindakan kelas (PTK) yang berjudul penerapan pendekatan CTL untuk meningkatkan hasil belajar siswa kelas VIII E SMPN 18 Sigi pada materi SPLDV,dengan pembelajaran contextual dalam pembelajaran matematika, diharapkan siswa lebih aktif, siswa tidak bosan dalam mengikuti pelajaran dan siswa dapat memahami pelajaran dengan baik melalui konteks kehidupan nyata siswa.

\section{Kerangka Teoretis}

Pembelajaran contextual merupakan konsep belajar yang dapat membantu guru mengaitkan isi materi yang diajarkan dengan situasi dunia nyata siswa dan mendorong siswa membuat hubungan antara pengetahuan yang dimilikinya dengan penerapannya dalam kehidupan mereka sebagai anggota keluarga dan masyarakat urhadi $^{1}$

Lebih lanjut, Howey R, Keneth mendefinisikan Contextual Teaching Learning (CTL) sebagai berikut ${ }^{2}$ :

"Contextual teaching is teaching that enable learning in wich student employ their academic understanding and abilities in a variety of inand out of school context to solve simulated or real wordl problems, both alone and with others." CTL adalah pembelajaran yang memungkinkan terjadinya proses belajar dimana siswa menggunakan pemahaman dan kemampuan akademiknya dalam berbagai konteks dalam dan luar sekolah untuk memecahkan masalah yang bersifat simulatif ataupun nyata, baik sendiri-sendiri maupun bersama-sama.

1 Rusman, Model-Model Pembelajaran Mengembangkan Profesionalisme Guru (Jakarta: Rajawali Press, 2012), 189.

2 Rusman, 190. 
Pendekatan CTL adalah pendekatan yang melibatkan siswa secara penuh dalam proses pembelajaran dan didorong untuk berkreativitas mempelajari materi pelajaran sesuai dengan topik yang akan dipelajari. Jadi, bukan hanya sekedar belajar mendengarkan dan mencatat, melainkan belajar adalah proses berpengalaman langsung dan diharapkan perkembangan siswa terjadi secara utuh, yang tidak hanya berkembang dalam aspek kognitif saja, tetapi juga aspek afektif dan juga psikomotor dan siswa menemukan sendiri materi yang dipelajarinya ${ }^{3}$

Menurut Wina Sanjaya karakteristik dalam proses pembelajaran yang menggunakan CTL yaitu ${ }^{4}$

1) Dalam CTL pembelajaran merupakan mengaktifkan pengetahuan yang sudah ada artinya apa yang akan dipelajari tidak terlepas dari pengetahuan yang sudah dipelajari, dengan demikian pengetahuan yang akan diperoleh siswa adalah pengetahuan yang utuh yang memiliki keterkaitan satu sama lain.

2) Pembelajaran yang CTL adalah belajar dalam rangka memperoleh dan menambah pengetahuan baru.

3) Pemahaman pengetahuan yang diperoleh bukan untuk dihafal tetapi untuk dipahami misalnya dengan cara meminta tanggapan dari yang lain tentang pengetahuan yang diperolehnya dan berdasarkan tanggapan tersebut baru pengetahuan itu dikembangkan.

4) Mempraktekkan pengetahuan dan pengalaman tersebut, pengetahuan dan pengalaman yang diperolehnya harus dapat diaplikasikan dalam kehidupan siswa, sehingga tampak perubahan prilaku siswa.

5) Melakukan refleksi strategi pengembangan pengetahuan, hal ini dilakukan sebagai umpan balik terhadap proses perbaikan dan penyempurnaan strategi.

${ }^{3}$ Suprihatiningrum Jamil, Strategi Pembelajaran Teori \& Aplikasi (Jogjakarta: Ar-Ruzz Media, 2013), 177-78.

4 Wina Sanjaya, Strategi Pembelajaran Berorientasi Standar Proses Pendidikan (Jakarta: Kencana, 2013), 110. 
Secara lebih sederhana karakteristik pembelajaran kontekstual dapat dinyatakan sebagai ${ }^{5}$ :

(1) Kerjasama, (2) Saling menunjang, (3) Menyenangkan, tidak membosankan, (4) Belajar dengan bergairah, (5) Pembelajaran terintegrasi, (6) Menggunakan berbagai sumber, (7) Siswa aktif, (8) Sharing dengan teman, (9) Siswa kritis guru kreatif, (10) Dinding dan lorong-lorong penuh dengan hasil kerja siswa, peta-peta, gambar, artikel, humor dan lain-lain, (11) Laporan kepada orang tua bukan hanya rapor tetapi hasil karya siswa, laporan hasil pratikum, karangan siswa dan lain-lain. Lebih lanjut dikatakana bahwa pembelajaran Contextual melibatkan tujuh komponen utama dari pembelajaran produktif yaitu : kontruktivisme (contructivisme). Membentuk grup belajar yang sangat membantu (interdependent learning grups). Menemukan (inquiry), bertanya (questioning), pemodelan (modelling), refleksi (reflection) dan penilaian yang sebenarnya (authentic assessment). Dari

\section{Metode dan Hasil Penelitian}

Pendekatan yang digunakan dalam penelitian ini yaitu pendekatan kualitatif dengan jenis Penelitian Tindakan Kelas (PTK) yang dikembangkan oleh Stephen Kemmis dan Mc Taggart. Subyek penelitian adalah siswa kelas VIII E SMPN 18 Sigi

Instrumen yang digunakan yaitu tes hasil belajar dan lembar observasi. Observasi dilakukan untuk mengamati aktivitas guru dan siswa selama proses pembelajaran dengan menggunakan pendekatan CTL. Instrumen lain yang juga digunakan dalam penelitian ini yaitu catatan lapangan yang diperoleh selama pelaksanaan penelitian yang memuat kejadian - kejadian dan fakta di kelas. Untuk menunjang data penelitian ini, dilakukan juga wawancara dengan siswa untuk melihat respon siswa mengenai proses pembelajaran.

\footnotetext{
${ }^{5}$ Widodo, "PTK: Upaya Meningkatkan Aktifitas dan Hasil Belajar Kimia Peserta Didik dengan Penggunaan Peta Konsep Melalui Pembelajaran Kooperatif Tipe STAD di SMA N 1 sumberejo Tanggamus," 2011, http://widodoimpression.wordpress.com.
} 
Analisis data dilakukan dengan mengacu pada model Miles Huberman (Wiriaatmadja 2012:139) yaitu : 1) Mereduksi data, 2) Menyajikan data, dan 3) Menyimpulkan data. Kemudian tahap - tahap pelaksanaan tindakan terdiri dari perencanaan, pelaksanaan, pengamatan, dan refleksi.

Penelitian ini dimulai dari observasi awal yang dilakukan peneliti sebagai kegiatan pra tindakan. Observasi dilakukan disekolah yang menjadi lokasi penelitaian yaitu SMP Negeri 18 Sigi pada bulan November 2015. Selain melakukan observasi, dilakukan pula persiapan perangkat pembelajaran dalam penelitian. Tes yang pertama dilakukan adalah melakukan tes awal terhadap siswa untuk mengetahui pemahaman awal siswa terhadap materi yang nantinya akan berpengaruh terhadap hasil belajar mereka. Informasi yang diperoleh setelah melakukan tes awal dari 18 siswa, hanya ada 8 orang siswa yang tuntas sedangkan 10 siswa yang belum mencapai ketuntasan,

Berdasarkan hasil dari tes awal, peneliti membagi siswa menjadi 4 kelompok dengan anggota yang memiliki kemampuan heterogen. Pembagian kelompok yang bersifat heterogen ini dimaksudkan agar siswa dapat saling memberi masukan-masukan antara sesama anggota kelompoknya, sehingga semua kelompok aktif selama proses pembelajaran berlangsung.

Pelaksanaan tindakan dilakukan oleh peneliti sendiri dengan koordinasi bersama guru mataplejaran hal ini dimaksudkan agar proses pembelajaran sepenuhnya dibawah pengawasan peneliti. Oleh karena itu dalam kegiatan pembelajaran peneliti dibantu oleh dua orang teman sejawat yang bertindak sebagai pengamat siswa dan pengamat guru. Dalam penelitian ini, setiap kelompok diberikan LKS, dan hasil pekerjaan siswa pada LKS kelompok pada siklus I diperoleh persentase KBK 66,66\% dan siklus II diperoleh presentase $100 \%$ artinya pada siklus I belum mencapai standar ketuntasan dan pada siklus II memenuhi ketuntasan. Sedangkan hasil pekerjaan siswa LKS individu pada siklus I diperoleh nilai yang tidak memenuhi standar ketuntasan yaitu 11 orang siswa, dengan persentase 61,11\%, sedangkan hasil analisis LKS individu pada siklus II mengalami peningkatan persentase sebesar $77,77 \%$. 
Setelah melaksanakan tes akhir pada siklus I dari 18 siswa yang mengikuti tes akhir, diperoleh persentase KBK 72,22\% dimana siswa yang tidak mencapai ketuntasan hanya 5 siswa. Sedangkan pada siklus II mengalami peningkatan dari 18 siswa yang mengikuti tes akhir, diperoleh persentase KBK 83,33\%. Dimana siswa yang memenuhi standar ketuntasan siswa adalah 15 siswa dari 18 jumlah keseluruhan siswa. Hal ini menunjukan bahwa hasil belajar siswa tentang materi sistem persamaan linear dua variabel meningkat.

Hasil observasi terhadap aktivitas siswa, observasi kelas dan wawancara dengan siswa selama mengikuti kegiatan pembelajaran ini diperoleh hasil sebagai berikut:

1) subyek cukup antusias mengikuti kegiatan pembelajaran.

2) subyek sangat gembira dan senang (endjoy) mengikuti kegiatan pembelajaran.

3) subyek perlu dimotivasi atau diarahkan oleh guru dalam menyelesaikan masalah matematika.

4) subyek masih rendah kemampuannya dalam hal memahami isi LKS, sehingga perlu penjelasan tambahan dari guru.

Sedangkan hasil observasi kegiatan guru menunjukan bahwa:

1) guru telah berusaha melaklsanakan kegiatan pembelajaran sesuai rencana yang telah dipersiapkan. Namun demikian waktu yang relatif terbatas tetap merupakan salah satu kendala yang perlu dipertimbangkan dalam pelaksanaan pembelajaran pada siklus berikutnya.

2) kadang-kadang penjelasan guru baik dalam memahami LKS maupun merangkum materi kurang dipahami subyek. Oleh karena itu penjelasan tersebut lebih disederhanakan dan diberikan contoh konkrit sehingga lebih mudah untuk dipahami subyek.

Berdasarkan hasil penelitian yang dilakukan tersebut, maka peneliti memperoleh gambaran bahwa CTL juga dapat membuat siswa terlibat aktif dalam kegiatan pembelajaran dari belajar secara kelompok maupun secara individu. Dengan adanya aktivitas kelompok dan individu yang diterapkan pendekatan CTL ini, dapat memberikan motivasi, pemahaman dan 
kemampuan siswa baik yang berkemampuan tinggi maupun yang berkemampuan rendah untuk terlibat aktif dalam proses pembelajaran. Menurut Howey R, Keneth (Rusman, 2013:190) bahwa CTL adalah pembelajaran yang memungkinkan terjadinya proses belajar dimana siswa menggunakan pemahaman dan kemampuan akademiknya. Dalam berbagai konteks dalam dan luar sekolah untuk memecahkan masalah yang bersifat simulatif ataupun nyata, baik sendiri maupun bersama. Hal ini terjadi karena dalam proses pembelajaran semua siswa dapat kesempatan yang sama. Selain itu, siswa yang berkemampuan tinggi termotivasi untuk membantu siswa yang lain dalam menyelseaikan tugas kelompok dalam bentuk LKS kelompok.

Keberhasilan pembelajaran dengan mengunakan pendekatan CTL yang mempunyai 7 komponen yaitu : (1) Kontruktivisme, (2) Bertanya, (3) Menemukan, (4) Masyarakat belajar, (5) Pemodelan , (6) Refleksi dan (7) Penilaian autentik dalam tindakan penelitian ini didukung oleh usaha peneliti untuk sebaik mungkin menginformasikan dan menjelaskan materi kepada siswa. Selain itu, berhasilnya tindakan pembelajaran juga didukung oleh sarana pembelajaran yang cukup memadai dan sangat membantu siswa. Bahan pembelajaran berupa berkas materi pembelajaran yang dibagikan kepada siswa yang merupakan rangkuman sistematis dari penjelasan guru dan adanya buku pegangan siswa dapat membantu, sebab siswa dapat menfokuskan konsentrasinya pada penjelasan guru dan lebih menghemat waktu untuk mencatat.

Secara umum penelitian ini menunjukan hasil belajar siswa pada materi pertidaksamaan linear satu variabel dengan menggunakan pendekatan Contextual Teaching and Learning (CTL) mengalami peningkatan dan berhasil. Indikator keberhasilan yang ditargetkan telah tercapai dengan beberapa catatn refleksi yang diharapkan dapat diperbaiki di waktu mendatang. 


\section{Penutup}

Berdasarkan hasil penelitian dan pembahasan, maka dapat disimpulkan beberapa hal sebagai berikut:

1. Dengan menerapkan pendekatan CTL pada materi sistem persamaan linear dua variabel (SPLDV) dapat meningkatkan hasil belajar siswa kelas VIII E SMPN 18 Sigi melalui 7 komponen pembelajaran pendekatan CTL yaitu, kontruktivisme, bertanya, inquiri, masyarakat belajar, modelling, refleksi dan penilaian sebenarnya. Hasil belajar siswa yang meningkat dilihat dari tes akhir siklus I yang mencapai skor rata-rata $72,22 \%$ dan siklus II mencapai skor rata-rata $83,33 \%$. Ini adalah bukti keberhasilan pembelajaran Matematika di kelas VIIIE SMPN 18 Sigi dengan Pendekatan CTL, sudah mencapai KKM yang ditetapkan sebesar 65, dengan kata lain pendekatan CTL dapat meningkatkan hasil belajar siswa

2. Pembelajaran matematika dengan menggunakan Pendekatan CTL pada materi sistem persamaan linear dua variabel (SPLDV) menunjukan suatu peningkatan, yang membantu siswa terlibat aktif dalam kegiatan pembelajaran baik secara kelompok maupun individu. Hal ini terjadi karena Pendekatan CTL merupakan Pendekatan Pembelajaran yang menghubungkan dengan kehidupan sehari-hari sehingga pembelajaran menjadi lebih termotivasi. Pembelajaran pendekatan contextual Teaching and Learning (CTL), dapat memberikan motivasi kepada siswa baik yang berkemampuan tinggi maupun berkemampuan rendah untuk terlibat aktif dalam proses pembelajaran. Hal ini terjadi disebabkan oleh pembagian anggota kelompok yang heterogen sehingga siswa termotivasi untuk bekerja sama dalam meyelesaikan tugas kelompok dalam bentuk LKS 


\section{Daftar Pustaka}

Jamil, Suprihatiningrum. Strategi Pembelajaran Teori \& Aplikasi. Jogjakarta: Ar-Ruzz Media, 2013.

Rusman. Model-Model Pembelajaran Mengembangkan Profesionalisme Guru. Jakarta: Rajawali Press, 2012.

Sanjaya, Wina. Strategi Pembelajaran Berorientasi Standar Proses Pendidikan. Jakarta: Kencana, 2013.

Widodo. "PTK: Upaya Meningkatkan Aktifitas dan Hasil Belajar Kimia Peserta Didik dengan Penggunaan Peta Konsep Melalui Pembelajaran Kooperatif Tipe STAD di SMA N 1 sumberejo Tanggamus," 2011. http://widodoimpression.wordpress.com. 